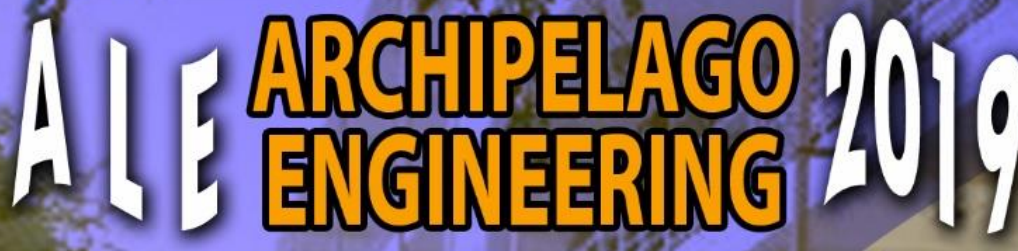

Fakultas Teknik Universitas Pattimura

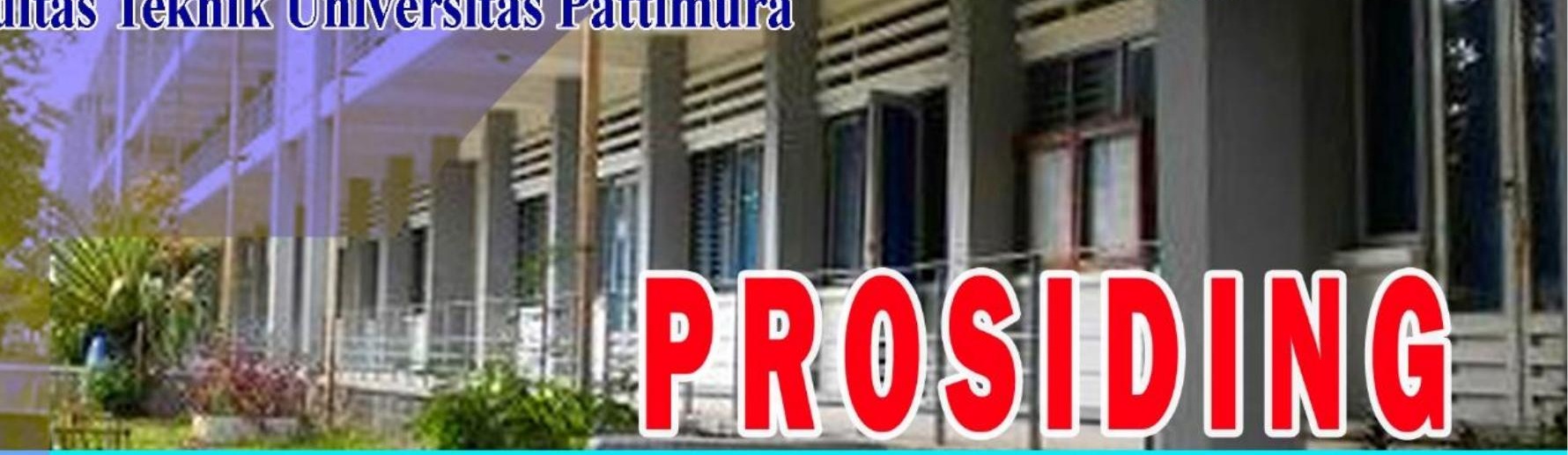

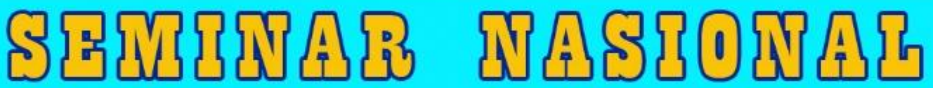

\section{ISSN: 2620-3995}

FAKULTAS TEKN IK UNIVERSITAS PATTIMURA KAMPUS POKA AMBON 10 APRIL 2019

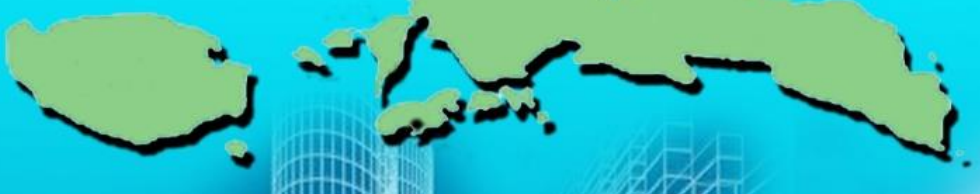

Hons

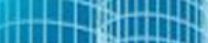

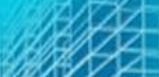

$102=0$
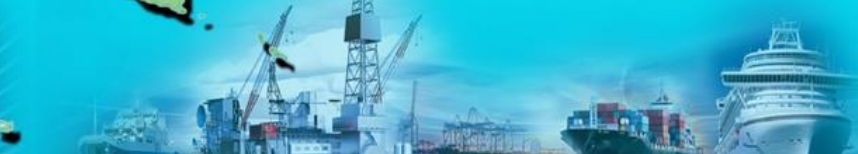

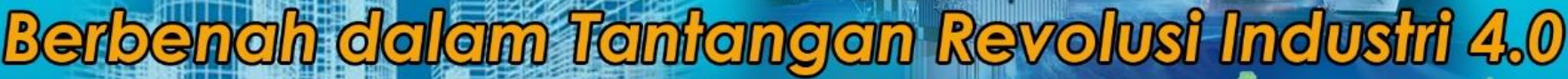

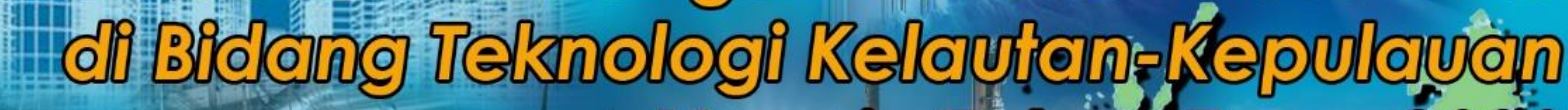

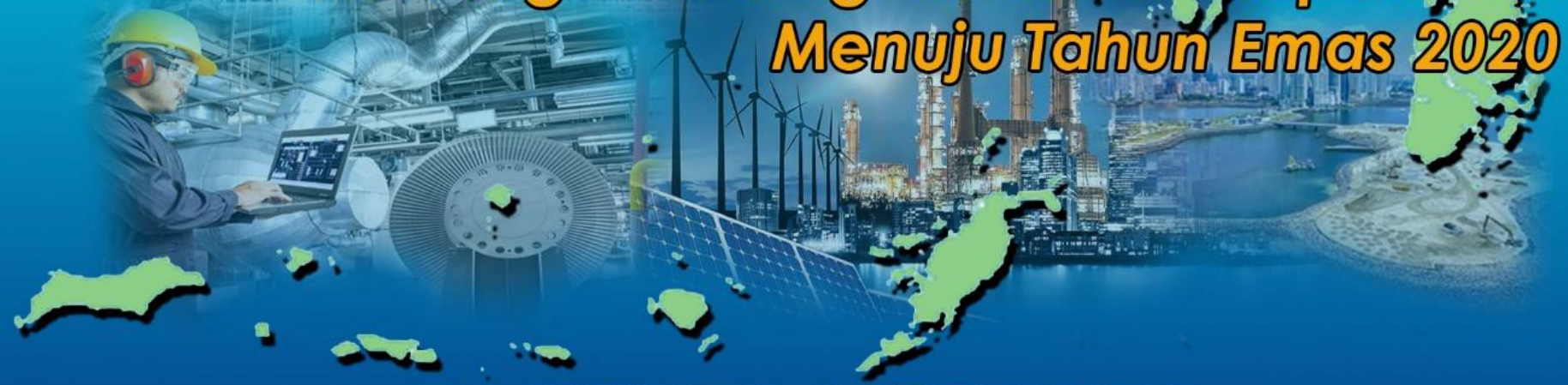

FARUITAS TREIRINIR

UINIVIRISITRAS PATTLIIIIURRA

ANBBON

2(1)129 

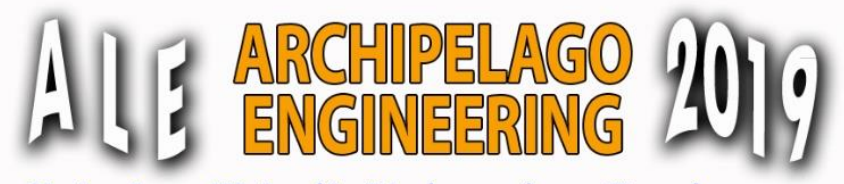

ISSN: 2620-3995

Fakultas Teknik Universitas Pattimura
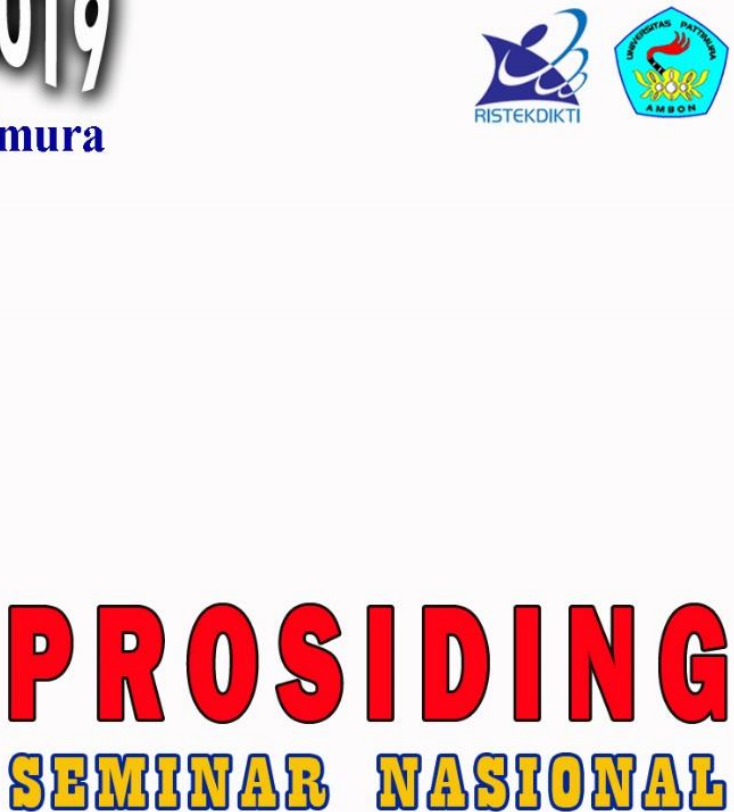

FAKULTASTEKNIK UNIVERSITAS PATTIMURA

KAMPUS POKA AMBON 10 APRIL 2019

Berbenah dalam Tantangan Revolusi Industri 4.0 di Bidang Teknologi Kelautan-Kepulauan Menuju Tahun Emas 2020

FAKULTAS TEKNIK

UNIVERSITAS PATTIMURA

AMBON

2019 


\section{SAMBUTAN DEKAN FAKULTAS TEKNIK UNPATTI}

Assalamulaikum Warohmatullahi Wabarakatuh,

Salam Sejahtera.

Marilah kita panjatkan puji syukur kepada Tuhan Yang Maha Kuasa yang telah memberikan rahmat dan karuniaNya sehingga kegiatan Seminar Nasional ke -2 Archipelago Engineering 2019 dengan tema "BERBENAH DALAM TANTANGAN REVOLUSI INDUSTRI 4.0 DI BIDANG TEKNOLOGI KELAUTAN KEPULAUAN MENUJU TAHUN EMAS 2020" dapat terselenggara dengan baik dan lancar.

Atas nama Keluarga Besar Fakultas Teknik Unpatti, perkenankan saya menyampaikan Selamat Datang di Kampus Fakultas Teknik kepada Bapak Prof. Adi Suryosatyo dari Universitas Indonesia, Bapak Dr. I Made Ariana, ST., MT. dari ITS dan dan Ibu Cathy Garden dari Selandia Baru sebagai Keynote Speakers, para pemakalah dan peserta dari luar Universitas Pattimura guna mengikuti seminar ini.

Saya menyambut gembira karena kegiatan Seminar ALE 2019 ini mendapatkan perhatian yang besar dari para dosen di lingkup Fakultas Teknik Unpatti sehingga lebih dari 40 makalah akan dipresentasikan dalam seminar ini. Untuk itu, saya menyampaikan terima kasih dan penghargaan yang setinggi-tingginya kepada Bapak dan Ibu para pemakalah. Saya yakin bahwa dari seminar ini akan menghasilkan ide-ide, konsepkonsep, teknik-teknik dan terobosan-terobosan baru yang inovatif dan bersinergi dengan pengembangan pola Ilmiah Pokok Unpatti terutama di bidang Kelautan Kepulauan.

Seminar ini terselenggara dengan baik karena dukungan dari berbagai pihak, khususnya para sponsor dan kontribusi dari pemakalah dan peserta. Untuk itu, saya menyampaikan terima kasih yang sebesarbesarnya.

Secara khusus, saya menyampaikan terima kasih dan penghargaan yang setinggi-tingginya kepada Panitia Penyelenggara atas jerih payah, kerja keras, ketekunan dan kesabarannya dalam mempersiapkan dan menyelenggarakan seminar ini sehingga dapat berjalan baik, lancar dan sukses.

Akhirnya, melalui seminar ini, marilah kita senantiasa perkuat dan perluas jejaring serta kerjasama antar sesama dosen sebagai pendidik, peneliti dan pengabdi kepada masyarakat dalam mewujudkan Tri Dharma Perguruan Tinggi guna membangun bangsa dan negara tercinta.

Ambon, 10 April 2019

Dekan Fakultas Teknik Unpatti,

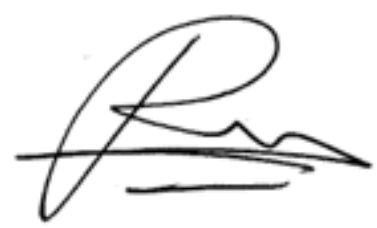

Dr. Ir. W. R. Hetharia, M.App.Sc 


\section{SUSUNAN PANITIA PELAKSANA 2019}

Dr. Novitha L. Th. Thenu, ST., MT

Nikolaus Titahelu, ST, MT

Dr. Debby R. Lekatompessy, ST., MT

Ir. W. M. E. Wattimena, MSc

Danny Pailin Bunga, ST, MT

Ir. Latuhorte Wattimury, MT

N. Maruanaya, SH

Ir. H. C. Ririmasse, MT

Ir. John Latuny, MT, PhD

SEKSI SEMINAR ALE 2019

W. M. Rumaherang, ST., MSc, PhD

D. S. Pelupessy, ST, MSc, PhD

Prayitno Ciptoadi, ST, MT Benjamin G. Tentua, ST, MT

Mercy Pattiapon, ST, MT Meidy Kempa, ST, MT 
HALAMAN JUDUL

Teknik Perkapalan, Teknik Transportasi Laut

E. R. de FRETES :

Analisa Parametrik Channel Flow pada Lambung Kapal Cepat untuk Memperoleh Wake Maksimum. Studi Kasus: Kapal Cepat Rute Ambon Wayame

SONJA TREISJE A. LEKATOMPESSY:

Pengaruh Variasi Parameter Pengelasan Terhadap Kualitas Hasil Pengelasan

OBED METEKOHY :

Analisa Pengaruh Karakteristik Teknis Desain Terhadap Proses Setting Kapal Pukat

Cincin di Maluku

HELLY S. LAINSAMPUTTY :

Analysis Of Principle Dimension And Shape Of Purse Seiners In Ambon Island

WOLTER R. HETHARIA, A. FENINLAMBIR, J. MATAKUPAN, F. GASPERSZ:

Pengaruh Dimensi Terhadap Parameter Stabilitas Kapal-Kapal Penumpang Kecil

Material FRP

LEKATOMPESSY DEBBY R, SOUMOKIL RUTH P, RIRIMASSE HEDY C. :

Analisa Response Dinamik Pada Sambungan Konstruksi Kapal Kayu Berdasarkan Tipe

Mesin Yang Digunakan

EDWIN MATATULA:

Studi Pemilihan Jenis Alat Angkut Bahan Bakar Minyak Wilayah Kepulauan

MONALISA MANUPUTTY :

Pengaruh Getaran Dan Kebisingan Terhadap Kelelahan Kerja Pada Awak Kapal Ikan

Tipe Pole And Line

\section{Teknik Sistem Perkapalan}

ABDUL HADI, B. G. TENTUA :

Algoritma Simulasi Numerik Getaran Dirrect Inline Harmonical Cam Follower Pada

Valve Train Manifold Motor Diesel

DANNY S. PELUPESSY :

Studi Karakteristik Momen Torsi Akumulator Pegas Untuk Penggerak Langkah (StepDrives)

JACOB D. C. SIHASALE, JERRY R. LEATEMIA :

Analisis Penampatan Lokasi Station AIS (Automatic Identification Sistem) Di Ambon

Guna Mendukung Monitoring ALKI (Alur Laut Kepulauan Indonesia) III Secara

Maksimal

LATUHORTE WATTIMURY :

Tinjauan Analisa Kerja Signal AF dan RF Terhadap Kinerja Peralatan Pemancar Dan

Penerima Stasiun Radio Pantai Distrik Navigasi Ambon

MESAK FRITS NOYA, ABDUL HADI :

Studi Eksperimental Pengaruh Posisi Pengelasan Terhadap Sifat Mekanis Baja Karbon

Rendah 
NOVITHA L. TH. THENU :

Pemisahan Sinyal Bunyi Dari Microphone Array Dengan Menggunakan Metode Blind

Source Separation - Independent Component Analysis Untuk Memantau Kondisi Poros

Retak

PRAYITNO CIPTOADI :

Pengaruh Variasi Diameter Pipa Isap Terhadap Karakteristik Pompa Sentrifugal

Teknik Mesin, Teknik Informatika, Teknik Elektro

ANTONI SIMANJUNTAK, JOHANIS LEKALETTE :

PLTS di Pulau Osi dan Permasalahannya

BENJAMIN GOLFIN TENTUA, ARTHUR YANNY LEIWAKABESSY :

Studi Eksperimental Sifat Mekanis Tarik dan Bending Komposit Serat Empulur Sagu

JANDRI LOUHENAPESY, SEFNAT J. ETWAN SARWUNA :

Analisa Kinerja Rem Cakera Akibat Modifikasi Kaliper Roda Belakang Terhadap

Keselamatan Pengendara Sepeda Motor

NICOLAS TITAHELU, CENDY S. E. TUPAMAHU:

Analisis Pengaruh Masukan Panas pada Oven Pengering Bunga Cengkeh Terhadap

Karakteristik Perpindahan Panas Konveksi Paksa

W. M. RUMAHERANG :

Evaluasi Karakteristik Energy Torque Converter Berdasarkan Pengaruh Rasio Putaran

Terhadap Koefesien Torsi dan Efesiensi

ELVERY B. JOHANNES :

Indexing pada Sistem Penalaran Berbasis Kasus Menggunakan Metode Complete-

Linkage Clustering

SAMY J. LITILOLY, NICOLAS TITAHELU :

Laser Semikonduktor GaAs Jenis Double Heterojunction Sebagai Sumber Cahaya dalam Komunikasi Optik

\section{Teknik Industri}

ALFREDO TUTUHATUNEWA :

Model Agile Supply Chain Industri Perikanan di Kota Ambon

AMINAH SOLEMAN :

Analisis Beban Kerja Mental Dan Fisik Karyawan Pada Lantai Produksi Dengan

Metode Nasa-Tlx Dan Cardiovascularload

DANIEL B. PAILLIN, JOHAN M TUPAN, RIZKI ANGGRAENI UTAMI PUTRI :

Penerapan Algoritma Differential Evolution untuk Penyelesaian Permasalahan

Capacitated Vehicle Routing Problem (CVRP). (Studi Kasus: PT. Paris Jaya Mandiri)

MARCY L. PATTIAPON, NIL EDWIN MAITIMU :

Perencanaan Produksi Kerajinan Kulit Kerang Mutiara dengan Menggunakan Metode

Agregat di Kota Ambon

J. M. TUPAN :

Desain Pemasaran Online Berbasis Web untuk Pemasaran Produk Kerajinan Kerang

Mutiara di Kota Ambon. (Studi Kasus: Pondok Mutiara)

NIL EDWIN MAITIMU, MARCY L. PATTIAPON :

Penerapan Economic Order Quantity (EOQ) Guna Menganalisa Pengendalian

Persediaan Bahan Baku Daging Buah Pala pada Usaha Kecil Menengah (UKM) Hunilai di Dusun Toisapu Desa Hutumuri

RICHARD A. de FRETES :

Pengembangan Komunitas Pesisir Di Kecamatan Leitimur Selatan dengan

Memanfaatkan Kearifan Lokal 
MOHAMMAD THEZAR AFIFUDIN, ARIVIANA LIENTJE KAKERISSA :

Aplikasi Pendekatan N-Stage untuk Masalah Pengrutean dan Penjadwalan TrukTunggal di Daerah Kepulauan. (Studi Kasus pada Koperasi Unit Bersama Negeri Booi, Saparua)

W. LATUNY :

Memprediksi Harga Jual Rumput Laut Kering Pada Tingkat Petani Dengan Data Mining

IMELDA CH. POCERATU :

Implementasi Ekoteologi dalam Pencegahan Pencemaran Lingkungan Laut di Pasar Arumbai Ambon

Teknik Sipil, Perencanaan Wilayah \& Kota

A. KALALIMBONG :

Tinjauan Hasil Peningkatan Saluran Suplesi Geren Meten Pulau Buru

S. G. M. AMAHEKA, FUAD H. OHORELLA, JESICA NAHUMURY :

Analisis Biaya Operasnal Kendaraan di Kota Ambon

MEIDY KEMPA :

Kajian Tentang Faktor-Faktor yang Mempengaruhi Keterlambatan Proyek Gedung di

Kota Ambon : Peringkat Faktor \& Solusi Penanggulangannya

SAMMYLES G. M. AMAHEKA, ARIVIANA L. KAKERISSA:

Pengaruh Penerapan Keselamatan Dan Kesehatan Kerja Terhadap Biaya Proyek

Konstruksi Bangunan Gedung di Kota Ambon

PIETER TH. BERHITU :

Model Stuktural Aspek Peran Zonasi dan Masyarakat dalam Pengelolaan Pesisir Kota

Ambon Berkelanjutan

\section{Tambahan}

RIKHARD UFIE, ROY R. LEKATOMPESSY, ZICO MARLISSA:

Kaji Kapasitas Pendinginan Ikan dengan Menggunakan Es dalam Kemasan Plastik

FELLA GASPERSZ, ABDUL DJABAR TIANOTAK, RUTH P. SOUMOKIL:

Kajian Kualitas Kelas Awet Limbah Batang Kulit Pohon Sagu Sebagai Material Alternatif Bangunan Kapal

ABDUL DJABAR TIANOTAK, H. C. RIRIMASSE, ELVERY B. JOHANNES:

Uji Kelayakan Ekonomis Pengembangan Fasilitas Bongkar Muat dan Turun Naiknya Penumpang di Pelabuhan Hurnala Maluku Tengah

H. C. RIRIMASSE, ABD. DJABAR TIANOTAK, ELVERY B. JOHANNES :

Penentuan Sistim Trasportasi Unggulan Di Kawasan Pengembangan Ekonomi

Terpadu (Kapet) Seram Provinsi Maluku

BILLY J. CAMERLING :

Pemilihan Alternatif Bahan Bakar Mesin Pembangkit PLTD Menggunakan Metode Value Engineering 
Kelamkak Bidana Kailean:

TEKNIIK MESINN

TEKNIIK INFORMATIIKA

FISIIKA 


\title{
STUDI EKSPERIMENTAL SIFAT MEKANIS TARIK DAN BENDING KOMPOSIT SERAT EMPULUR SAGU
}

\author{
Benjamin Golfin Tentua ${ }^{1)}$, Arthur Yanny Leiwakabessy ${ }^{2)}$ \\ 1)benjamin.tentua@fatek.unpatti.ac.id, ${ }^{2}$ arthur.leiwakabessy@gmail.com
}

Fakultas Teknik Universitas Pattimura - Ambon

\begin{abstract}
ABSTRAK
Serat ampas sagu merupakan sissa dari pengolahan sagu yang biasa dipergunakan sebagai bahan pakan ternak oleh masyarakat setempat. Dalam penelitian ini serat empulur sagu akan dikembangkan menjadi bahan komposit yang dapat dipergunakan sebagai material dalam bidang teknik.

Penelitian dilakukan secara eksperimental untuk mengetahui pengaruh fraksi volume antara serat empelur sagu dan resin polyester terhadap nilai kekuatan tarik dan kekuatan bending material komposit dengan variable pengujian fraksi volume serat empelur sagu 10\%, 20\%, 30\% dan $40 \%$.

Hasil pengujian menunjukan bahwa nilai kekuatan tarik dan bending komposit mengalami peningkatan sesauai dengan perubahan fraksi volume serat serat empelur sagu. Dimana nilai tertinggi untuk kekuatan tarik yaitu 10,4 MPa pada fraksi volume $40 \%$ dan terendah pada fraksi volume $10 \%$ yaitu 6,03 MPa.

Untuk hasil pengujian bending nilai tertinggi berada pada fraksi volume $40 \%$ sebesar 2,86 MPa dan nilai terendah berada pada fraksi volume $10 \%$, sebesar 2,02 MPa. Peningkatan kekuatan tarik dan bending secara umum dipengaruhi oleh daya ikat antara serat dengan matriks yang sempurna serta penambahan volume fraksi serat Empelur Sagu pada komposit.
\end{abstract}

Kata Kunci: Serat Empelur Sagu, Fraksi Volume, Uji Tarik, Uji Bending

\section{PENDAHULUAN}

Isu lingkungan, kelangkaan sumber daya, tuntutan konsumen akan kualitas produk yang semakin tinggi, pengetahuan, dan penguasaan ilmu yang semakin tinggi serta berbagai faktor lain yang merangsang terciptanya produk komposit yang berkualitas tinggi dari bahan baku yang berkualitas rendah.

Serat empelur sagu merupakan sisa olahan sagu yang terbuang dan biasa dipergunakan oleh masyarakat sebagai bahan pakan ternak. Maluku memiliki hutan sagu dengan luas 58.185 ha. untuk kondisi hutan sagu di Maluku rata-rata pohon sagu masak tebang adalah 20 pohon/ha dan rataan produksi tiap pohon adalah $220 \mathrm{~kg}$, sehingga dalam luasan satu ha dapat diproduksi $4400 \mathrm{~kg}$ tepung sagu. Hal ini berarti potensi serat ampas sagu tersedia cukup besar yaitu $1320 \mathrm{~kg}$ per pohon (Rumalatu 1989). Oleh sebab itu pemanfaatan serat empelur sagu sebagai penguat bahan komposit di bidang rekayasa merupakan salah satu alterative yang dapat dikembangkan.Material komposit merupakan bahan yang homogen yang dibuat dengan cara penggabungan fisis antara dua atau lebih jenis material untuk memperoleh karakteristik dan sifat tertentu yang diinginkan. Penggabungan material ini dimaksudkan untuk menemukan atau mendapatkan material baru yang mempunyai sifat antara (intermediate) material penyusunnya.

Sifat material hasil penggabungan makro ini diharapkan saling memperbaiki kelemahan dan kekurangan bahan- bahan penyusunnya. Adapun beberapa sifat- sifat yang dapat diperbaiki antara lain: kekuatan, kekakuan, ketahanan korosi, ketahanan aus, berat, attractive, ketahanan lelah, pengaruh terhadap temperatur, isolasi panas, penghantar panas, isolasi akustik (Jones, 1999). Untuk itu dalam penelitian ini akan ditinjau sifat kekuatan tarik dan bending dari komposit serat empelur sagu.

\section{KAJIAN TEORI DAN METODE 1. KAJIAN PUSTAKA}

Jamasri (2005) melakukan penelitian komposit serat buah sawit acak bermatrik polyesteri . Limbah serat sawit dicuci dengan air dan dikeringkan secara alami di dalam ruangan. Untuk mengetahui kandungan air serat dilakukan dengan pemanasan dalam oven pada suhu 62oC. Serat dengan diameter $1 \mathrm{~mm}$ dengan panjang 4-6 cm dipergunakan sebagai penguat pada komposit dengan matrik unsaturated polyester dengan resin 157 BQTN (UPRs) dan 1\% (w/w) hardened metil etil keton peroksid (MEKPO). Pembuatan komposit dilakukan dengan metode cetak tekan untuk variasi fraksi berat. Sedangkan harga modulus dan regangan patah untuk fraksi berat sampai 30\% tidak memberikan peningkatan yang signifikan dan terjadi peningkatan fraksi diatas 36\%.(Jamasri, 2005)

Arif (2008) meneliti pengaruh fraksi volume serat kelapa pada komposit matrik poliyester terhadap kekuatan tarik, impak dan bending dengan mempersiapkan serat kelapa dengan panjang $1 \mathrm{~cm}$ dengan panjang $1 \mathrm{~cm}$. Serat kelapa dengan panjang 1 
$\mathrm{cm}$ matrik polyester dengan variasi fraksi volume serat sebesar 5\%, 10\%, 20\% dan 30\%. Dari hasil pengujian didapatkan uji tarik terbaik $3,63 \mathrm{~kg} / \mathrm{mm} 2$ pada $3,18 \mathrm{Kg} / \mathrm{mm} 2$, pada fraksi volume $30 \%$ juga diperoleh nilai impact sebesar 2,61 J/m2. (Arif, 2008)

N.V. Rachchh, D.N. Trivedi (2018) dengan penelitiannya yaitu Mechanical Characterization and Vibration Analysis of Hybrid E-glass/Bagasse Fiber Polyester Composites, penelitian dilakukan dengan menggunakan serat tebu dengan presentase $3 \%, 6 \%$, 9\%, 12\%, dan $15 \%$ dan Fiber mamt sebesar $17 \%$ untuk semua variasi. Metode Pengecoran composit dilakukan dengan metode hand lay up. Hasil yang diperoleh menunjukan bahwa terjadi kenaikan sifat mekanik pada presentase bagase 9\%. Selain itu getaran yang terjadi memberikan nilai yang baik.

Saurab Dhakal, Keerthi Gowda B S (2016) dengan judul penelitiannya An Experimental Study on Mechanical properties of Banana Polyester Composite. Penelitian dilakukan dengan menggunakan serat banana dan fiber reinforced. Variable yang digunakan yaitu perbandingan fraksi volume $5,10,15,17.5$, dan $20 \%$ dengan metode frabrikasi yaitu hot compression moulding. Pengujian yang dilakukan adalah kekuatan tarik, bending, dan impact dengan ketebalan specimen 3 mmn dan $5 \mathrm{~mm}$ mengikuti standar ASTM D3039, ASTM D7264 and ASTM D256. Hasil yang diperoleh menunjukan nilai maksimum ada pada fraksi volume 5\% dengan kekuatan tarik 23.04 Mpa, kekuatan bending $124.61 \mathrm{Mpa}$ and dan impact $147.15 \mathrm{~J} / \mathrm{m}$.

\section{Material Komposit}

Komposit adalah suatu material yang terdiri dari campuran atau kombinasi dua atau lebih material baik secara mikro atau makro, dimana sifat material yang tersebut berbeda bentuk dan komposisi kimia dari zat asalnya (Smith, 1996). Pendapat lain mengatakan bahwa komposit adalah sebuah kombinasi material yang berfasa padat yang terdiri dari dua atau lebih material secara skala makroskopik yang mempunyai kualitas lebih baik dari material pembentuknya (Imra, 2009; Jacob, 1994).

Jenis material pembentuk komposit dapat dikelompokkan ke dalam empat bagian, yaitu:
1. Matrik
2. Material penguat (reinforcement)
3. Material pengisi (filler)
4. Material penambah (additive)

Karena itu semakin banyak pengetahuan tentang bahan pembentuk termasuk interaksi di antaranya, akan sangat membantu dalam menciptakan produk komposit yang mempunyai kemampuan maksimal.
Sebaliknya, bila kurang cermat dalam pemilihan bahan akan sangat merugikan.

\section{Metode Pembuatan Polimer Matrik Komposit}

Pembuatan Polimer Matriks komposit dapat dilakukan dengan beberapa cara antara lain :

\section{Proses Cetakan Terbuka (Open-Mold Process)}

Proses pembuatan cetakakan terbuka dapat dibedakan menjadi 5 cara yaitu :

\section{a. Contact Molding/ Hand Lay Up}

Resin dituangkan diatas serat didalam rongga cetakan seperti Gambar 1 dengan cara manual. Resin langsung berkontak dengan udara, biasanya proses pencetakan dilakukan pada temperatur kamar.

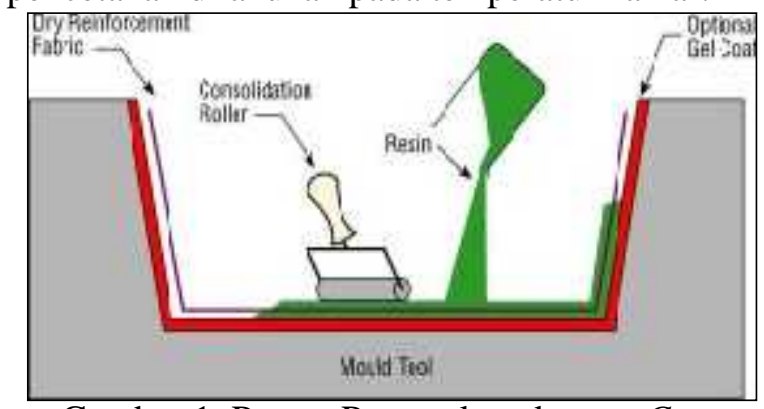

Gambar 1. Proses Pencetakan dengan Contact Molding/Hand Lay-Up (Smith, 1996)

\section{b. Vacuum Bag}

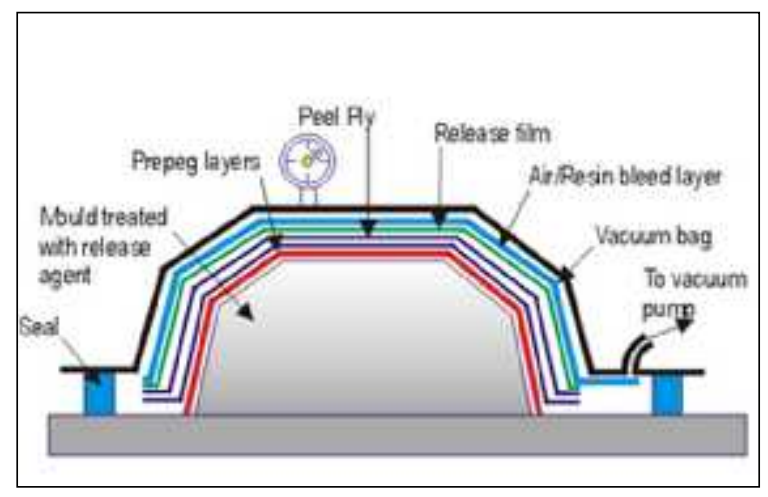

Gambar 2. Proses Pencetakan dengan Vacuum Bag (Jacobs, 1994)

Menggunakan pompa vacuum (Gambar 2) untuk menghisap udara yang ada dalam wadah tempat diletakkannya komposit yang akan dilakukan proses pencetakan. Udara yang ada diluar penutup plastic akan menekan kearah dalam. Hal ini akan menyebabkan udara yang terperangkap dalam specimen komposit akan dapat diminimalkan.

\section{c. Pressure Bag}

Memiliki kesamaan dengan metode vacuum bag, namun cara ini tidak memakai pompa vakum tetapi menggunakan udara atau uap bertekanan yang dimasukkan malalui suatu wadah elastis (Gambar 3). Wadah elastis ini yang akan berkontak pada komposit yang akan dilakukan proses. 


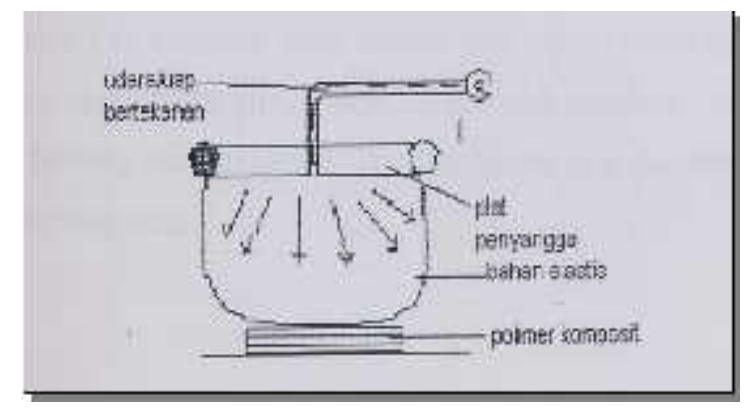

Gambar 3. Proses Pencetakan dengan Pressure Bag (Jacobs, 1994)

\section{d. Spray-Up}

Proses spray-up dilakukan dengan cara penyemprotan serat (fibre) yang telah melewati tempat pemotongan (chopper). Sementara resin yang telah dicampur dengan katalis juga disemprotkan secara bersamaan (Gambar 4). Wadah tempat pencetakan spray- up telah disiapkan sebelumnya.

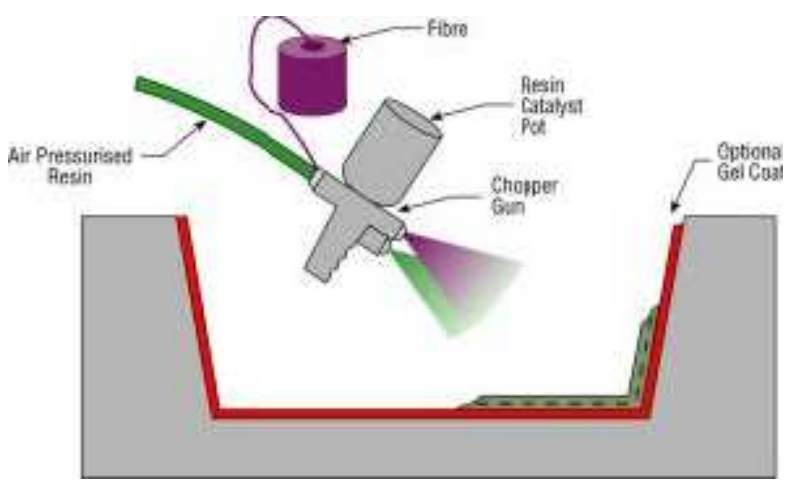

Gambar 4. Proses Pencetakan dengan Spray-Up (Smith, 1996)

\section{e. Filament Winding}

Fiber tipe roving atau single strand dilewatkan melalui wadah yang berisi resin (Gambar 5), kemudian fiber tersebut akan diputar sekeliling mandrel yang sedang bergerak dua arah, arah radial dan arah tangensial. Proses ini dilakukan berulang, sehingga cara ini didapatkan lapisan serat dan fiber sesuai dengan yang diinginkan.

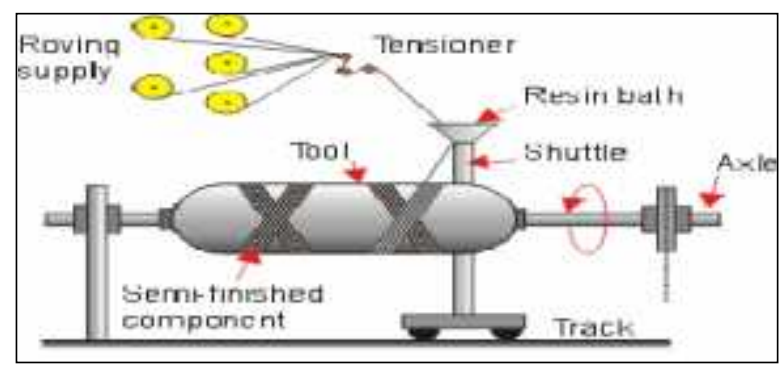

Gambar 5. Proses Pencetakan dengan Filament Winding (Smith, 1996)
2. Proses Cetakan Tertutup (Closed mold Processes)

a. Proses Cetakan Tekan (Compression Molding)

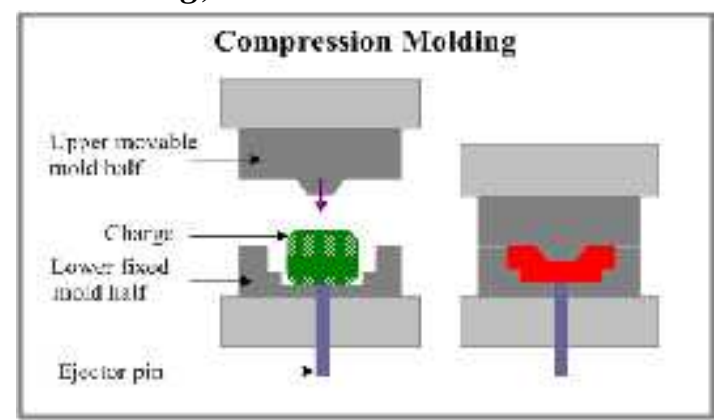

Gambar 6. Proses Pencetakan dengan Compression Molding (Callister, 1991)

Proses cetakan ini menggunakan hydraulic sebagai penekannya. Fiber yang telah dicampur dengan resin dimasukkan ke dalam rongga cetakan, kemudian dilakukan penekanan dan pemanasan.

\section{b. Injection Molding}

Fiber dan resin dimasukkan kedalam rongga cetakan bagian atas, kondisi temperatur dijaga supaya tetap dapat mencairkan resin. Resin cair beserta fiber akan mengalir ke bagian bawah, kemudian injeksi dilakukan oleh mandrel ke arah nozel menuju cetakan (Gambar 7)

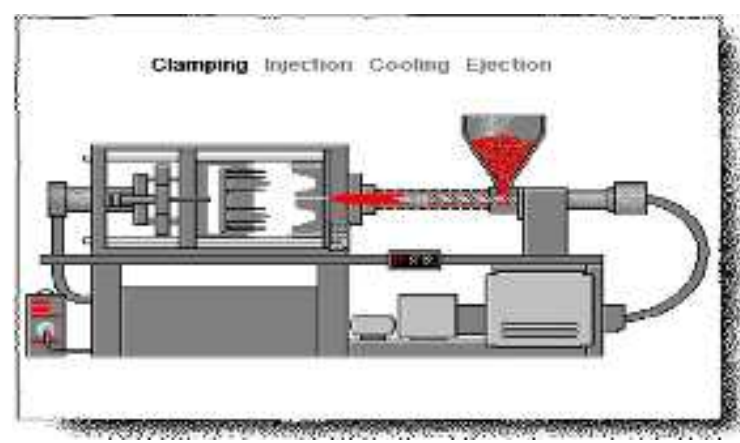

Gambar 7. Proses Pencetakan dengan Injection Molding (Jacobs, 1994)

\section{c. Continuous Pultrusion}

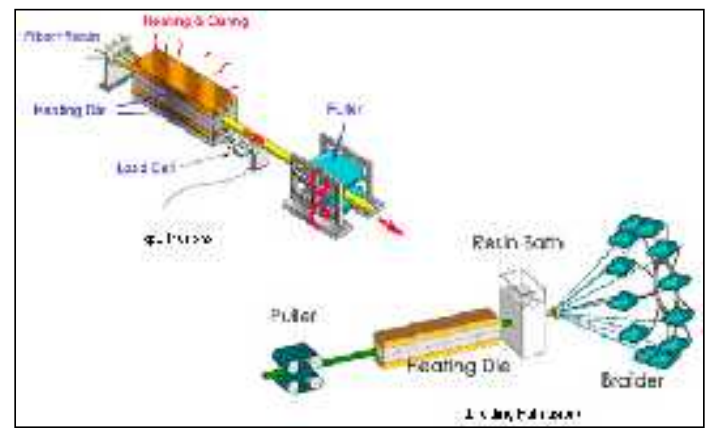

Gambar 8. Proses Pencetakan dengan Continuous Pultrusion (Callister, 1996) 
Fiber jenis roving dilewatkan melalui wadah berisi resin, kemudian secara kontinu dilewatkan ke cetakan pra cetak dan diawetkan (cure), kemdian dilakukan pengerolan sesuai dengan dimensi yang diinginkan (Gambar 8.).

\section{Pengujian Material Komposit.}

\section{a. Pengujian Tarik}

Pengujian tarik bertujun untuk mengetahui tegangan, regangan, modulus elastisitas bahan dengan cara memberikan beban tarik secaraberlahan sampai material komposit mengalami putus. Adapun keuletan material, daerah elastisitas dan plastis serta titik putus akan terlihat dari grafik yang ada. Dalam pengujian kekuatan tarik ini menggunakan standart ASTM ASTM D638-97.
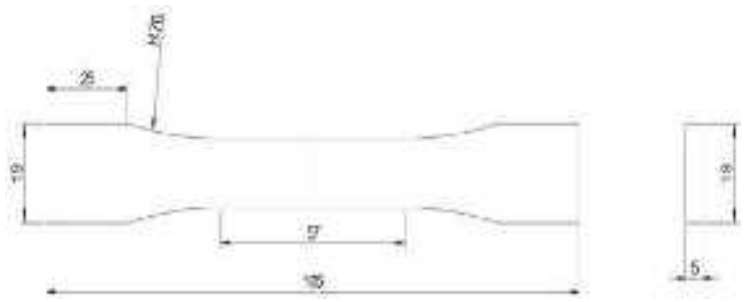

Gambar 9. Sampel kekuatan Tarik menurut standard ASTM D638-97

Kekuatan tarik komposit dipengaruhi oleh beberapa hal, antara lain:

1. Temperatur

Apabila temperatur naik, maka kekuatan tariknya akan turun.

\section{Kelembaban}

Pengaruh kelembaban ini akan mengakibatkan bertambahnya absorbs air akibatnya akan menaikan regangan patah.Sedangkan tegangan patah dan modulus elastisitasnya akan menurun.

\section{Laju tegangan}

Apabila laju tegangan kecil, maka perpanjangan bertambah dan mengakibatkan kurva teganganregangan menjadi landai, moduluselastistasnya rendah. Sedangkan jika laju tegangan tinggi, maka beban patah dan modulus elastisitasnya meningkat, tetapi regangan mengecil.

Hubungan antara tegangan tarik dan regangan pada beban tarik ditentukan dengan rumus sebagai berikut: (Kurniawan, K., 2012) Nilai tegangan dapat dicari dengan rumus :

$\sigma=\frac{r}{A}$ 1

Dimana: $\sigma=$ Tegangan tarik $(\mathrm{N} / \mathrm{mm} 2)$

$$
\begin{aligned}
& \mathrm{P}=\text { Beban }(\mathrm{N}) \\
& \mathrm{A}_{0}=\text { Luas penampang patahan }
\end{aligned}
$$

Untuk nilai regangan dapat dicari dengan rumus :
$\varepsilon=\frac{\Delta L}{L}$

Dimana: $=$ Tegangan-Regangan $(\%)$

$$
\begin{array}{ll}
\Delta \mathrm{L} & =\text { Deformasi }(\mathrm{mm}) \\
\mathrm{L} & =\text { Panjang daerah ukur }(\mathrm{mm}) \\
\mathrm{Lo} & =\text { Panjang mula-mula }(\mathrm{mm})
\end{array}
$$

Sedangkan modulus elastisitas dapat dicari dengan rumus :

$E=\frac{\sigma}{\varepsilon}$

Dimana: $\mathrm{E}=$ Modulus elastisitas $(\mathrm{N} / \mathrm{mm} 2)$

$$
\begin{aligned}
\sigma & =\text { Tegangan tarik }(\mathrm{N} / \mathrm{mm} 2) \\
& =\text { Tegangan-regangan }(\%)
\end{aligned}
$$

\section{b. Pengujian Bending}

Uji bending merupakan bentuk pengujian untuk mengetahui kekuatan bending suatu material.Pada uji bending,spesimen yang berbentuk batang ditempatkan pada dua tumpuan lalu diterapkan beban ditengah tumpuan dengan laju pembebanan konstan.
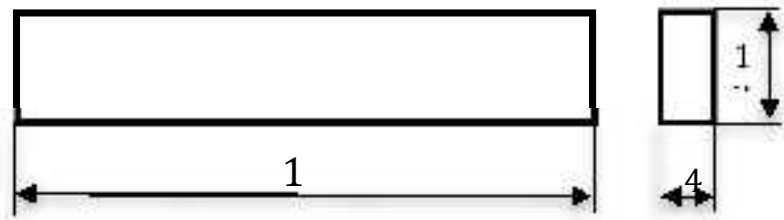

Gambar 10. Dimensi spesimen uji lentur ASTM D 790 (Calliester, 2007)

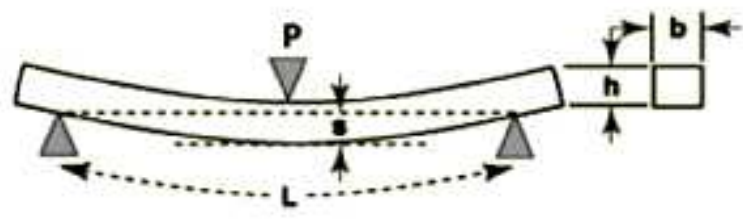

Gambar 11. Penampang bending (balok) Sumber : ASTM D 790, 1997

Dalam material komposit kekuatan tekannya lebih tinggi dari pada kekuatan tariknya. Karena tidak mampu menahan tegangan tarik yang diterima, spesimen tersebut akan patah, hal tersebut mengakibatkan kegagalan pada pengujian komposit. Kekuatan bending pada sisi bagian atas sama nilai dengan kekuatan bending pada sisi bagian bawah.

Kekuatan bending komposit dapat ditentukan dengan persamaan 4. (ASTM D 790-02):

$\sigma_{b}=\frac{3 P}{2 b h^{2}}$

dengan :

$$
\begin{aligned}
& \sigma_{\mathrm{b}}=\text { Tegangan bending }(\mathrm{MPa}) \\
& \mathrm{P}=\text { Beban } / \text { Load }(\mathrm{N}) \\
& \mathrm{L}=\text { Panjang Span } / \text { Support span }(\mathrm{mm}) \\
& \mathrm{b}=\text { Lebar } / \text { Width }(\mathrm{mm}) \\
& \mathrm{h}=\text { Tebal } / \text { Depth }(\mathrm{mm})
\end{aligned}
$$

Modulus elastisitas bendingnya dapat dirumuskan dengan persamaan 5 . 
$E_{b}=\frac{L^{\sharp} m}{4 b h^{\Xi}}$

dengan :

$\mathrm{E}_{\mathrm{b}} \quad=$ Modulus Elastisitas Bending (MPa)

$\mathrm{L} \quad=$ Panjang Span / Support span $(\mathrm{mm})$

$\mathrm{b}=$ Lebar/Width $(\mathrm{mm})$

$\mathrm{h}=$ Tebal $/$ Depth $(\mathrm{mm})$

$\mathrm{m}=$ Slope Tangent pada kurva beban defleksi $(\mathrm{N} / \mathrm{mm})$

\section{Metode Penelitian}

Desain penelitian yang digunakan dalam penelitian ini adalah ekperimental yang memvariasikan komposisi serat pengguat dengan menggunakan serat empelur sagu, dengan komposisi serat $10 \%$, $20 \%, 30 \%$, dan $40 \%$.

Untuk mencapai tujuan penelitian maka tahapantahapan yang dilakukan dalam penelitian ini terbagi atas berapa tahapan yaitu tahapan pembuatan specimen, tahapan pengecoran specimen dan tahapan pengujian specimen.

a. Tahapan Pembuatan specimen

1. Pengambilan serat ampas empur sagu yang sudah selesai di proses

2. Serat ampas empulur sagu di potong dengan ukuran panjang $10 \mathrm{~mm}$

3. Se.rat ampas empulur sagu dapat digunakan.

4. Melakukan perlakuan alkali dengan merendam dalam Larutan $\mathrm{NaOH}$.

5. Serat ampas empulur sagu dikeringkan secara alami dengan suhu ruangan, agar kandungan air didalam serat dapat diminimalisasikan.

b. Tahapan Pengecoran Spesimen

Langkah-langkang pembuatan spesimen bahan komposit pada penelitian ini adalah :

1. Penimbangan Serat ampas empulur sagu dan polyester dengan fraksi volume yang divariasikan.

2. Pencampuran serbuk batang kelapa dan polyester dilakukan dengan cara dicampur, kemudian dituangkan ke dalam cetakan dengan menambah katalis $1 \%$.

3. Spesimen dilepaskan dari cetakan dan dilakukan proses finishing untuk menghilangkan bekas2 polyester yang keluar dari cetakan

c. Tahapan Pengujian

a. Pengujian Tarik

Pada proses pengujian tarik material yang telah terbentuk dibuat dalam bentuk specimen pengujian tarik sesuai standart ASTM D63879 kemudian dilakukan pengujian sesuai Standrat prosedur alat pengujian tarik.

b. Pengujian Bending.

Pengujian bending bertujuan untuk mengetahui besarnya kekuatan lentur dari material komposit. Pengujian dilakukan dengan memberi beban lentur secara perlahan-lahan sampai spesimen mencapai titik lelah. Pada perlakuan uji bending bagian atas specimen mengalami proses penekanan dan bagian bawah mengalami proses tarik sehingga akibatnya spesimen mengalami patah bagian bawah karena tidak mampu menahan tegangan tarik. Spesimen uji bending dibuat sesuai standar ASTM D790 -

02. Tahapan proses pengujian bending yaitu :

1. Mempersiapkan benda uji.

2. Menentukan titik tumpuan dan titik tengah benda uji

3. Menentukan besarnya beban yang digunakan.

4. Meletakkan spesimen pada meja mesin pengujian bending dengan jarak tumpuan dan titik tengah yang telah ditentukan.

5. Putar handle sampai beban menyentuh benda uji dan manometer indikator menunjukkan angka nol.

6. Mencatat hasil pengujian bending setiap putaran yang telah ditentukan.

\section{HASIL DAN PEMBAHASAN}

\section{Kekuatan Tarik dan kekuatan Bending}

Dari hasil pengujian tarik dan bending diperoleh data hasil pengujian seperti pada table 1 .

\begin{tabular}{|c|c|c|c|c|c|}
\hline No & $\begin{array}{l}\text { Fraksi } \\
\text { Volum } \\
\text { e }\end{array}$ & \multicolumn{2}{|c|}{$\begin{array}{c}\text { Kekuatan Tarik } \\
(\mathrm{MPa})\end{array}$} & \multicolumn{2}{|c|}{$\begin{array}{c}\text { Kekuatan } \\
\text { Bending } \\
\text { (Mpa) }\end{array}$} \\
\hline \multirow{3}{*}{1} & \multirow{3}{*}{$10 \%$} & 1 & 8 & 1 & 2,16 \\
\hline & & 2 & 4.04 & 2 & 1,46 \\
\hline & & 3 & 5.07 & 3 & 2,45 \\
\hline \multirow{3}{*}{2} & \multirow{3}{*}{$20 \%$} & 1 & 6.05 & 1 & 2,48 \\
\hline & & 2 & 6.02 & 2 & 2,6 \\
\hline & & 3 & 8.09 & 3 & 2,53 \\
\hline \multirow{3}{*}{3} & \multirow{3}{*}{$30 \%$} & 1 & 7.00 & 1 & 2,38 \\
\hline & & 2 & 11.01 & 2 & 2,72 \\
\hline & & 3 & 7.04 & 3 & 1,56 \\
\hline \multirow{3}{*}{4} & \multirow{3}{*}{$40 \%$} & 1 & 12.04 & 1 & 1,78 \\
\hline & & 2 & 13.06 & 2 & 3,72 \\
\hline & & 3 & 5.21 & 3 & 3,08 \\
\hline
\end{tabular}

Hasil Pengujian Tarik menunjukan adanya perubahan kekuatan tarik pada setaiap fraksi volume. Peningkatan nilai kekuatn tarik sebanding dengan jumlah fraksi volume serat empelur sagu. Peningkatan kekuatan tarik 
maximum pada fraksi volume serat empelur sagu $40 \%$ yaitu sebesar 10,4 MPa.

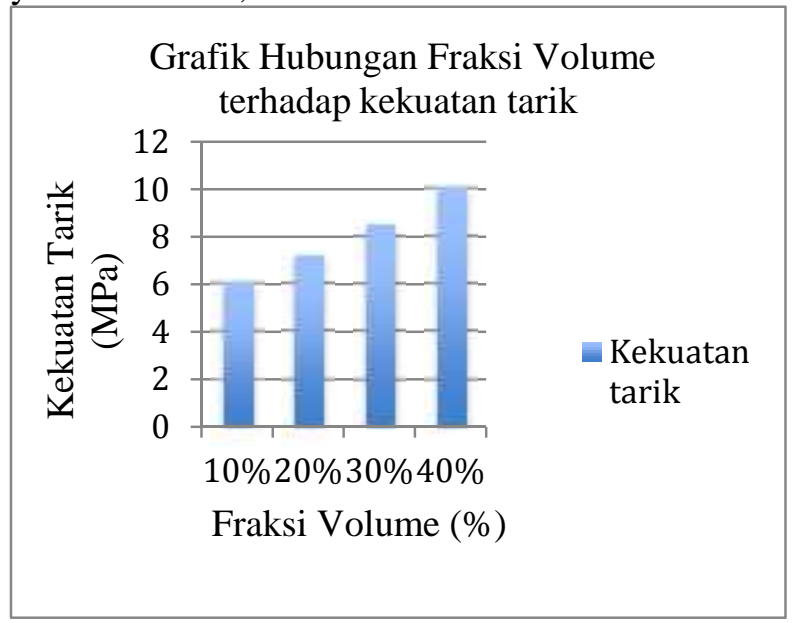

Gambar 12. Grafik Hubungan Fraksi Volume Terhadap Kekuatan Tarik Komposit Serat Empelur Sagu.

Hal ini dipengaruhi oleh daya ikat antara serat dengan matriks yang sempurna serta penambahan volume fraksi serat Empelur Sagu dalam matriks komposit.

Selain itu, faktor lain yang mempengaruhi peningkatan kekuatan tarik komposit adalah orientasi serat dalam komposit tersebut.

Serat yang mempunyai orientasi serat searah sesuai dengan panjang komposit ketika komposit menerima gaya tarik maka matriks komposit akan menahan gaya tersebut dan diteruskan ke serat sebelum akhirnya komposit tersebut akan putus/patah.

Untuk hasil pengujian bending Komposit serat empelur sagu cenderung mengalami kenaikan tegangan bending seiring dengan bertambahnya fraksi volume, disebabkan kekuatan serat yang mendominasi pada kekuatan komposit. Hasil pengujian kekuatan bending komposit berpenguat serat empelur sagu dapat dilihat pada gambar 5.2.

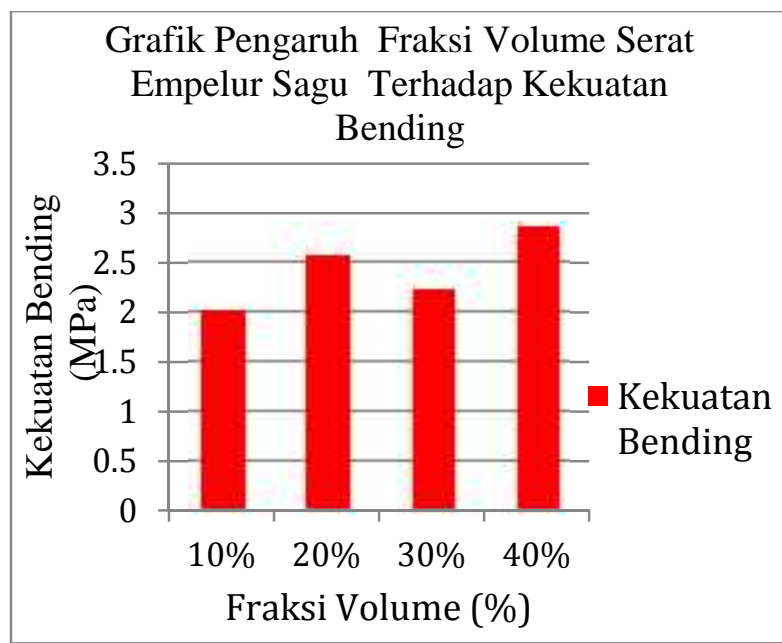

Gambar 13. Grafik Hubungan Fraksi Volume Terhadap Kekuatan Bending Komposit Serat Empelur Sagu.
Peningkatan fraksi volume serat komposit akan meningkatkan tegangan bending. Pada fraksi volume $40 \%$ kekuatan bending sebesar 2,86 dan terendah pada fraksi volume $10 \%$ yaitu sebesar 2,02.

Hal ini terjadi karena beban bending yang diterima material akan ditahan oleh matrik yang kemudian diteruskan merata pada serat. Semakin banyak kandungan seratnya maka beban yang diterima setiap serat akan semakin kecil, sehingga beban yang dapat ditahan akan semakin besar.

\section{Kesimpulan}

Dari hasil pengujian dan pembahasan yang dilakukan dapat disimpulkan bebarapa hal :

1. Kekuatan tarik material komposit dengan penguat serat empelur sagu memiliki kekuatan tarik semakin tinggi sesuai dengan peningkatan fraksi volume serat empelur sagu. Dimana pada fraksi volume $40 \%$ kekuatan tarik material komposit $10,4 \mathrm{MPa}$, dan terendah pada fraksi volume $10 \%$ yaitu 6,03 MPa.

2. Kekuatan bending dari material komposit serat empelur sagu yang tertinggi pada fraksi volume $40 \%$ yaitu sebesar 2,86 MPa dan terendah pada fraksi volume serat empelur sagu $10 \%$ yaitu sebesar 2,02 MPa.

\section{DAFTAR PUSTAKA}

Arif, Yunito Akhmad, 2008, Analisa Pengaruh Fraksi Volume Serat Kelapa PadaKomposit Matriks Polyester Terhadap Kekuatan Tarik, Impact Dan Bending, Teknik Material, ITS, Surabaya.

Bhavik Vaghasia et,al, 2018, Evaluation of Physical and Mechanical Properties of Woven Bamboo Glass Polyester Hybrid Composite Material,ScienceDirect material Proceedings page 7930-7936

Jacobs, J.A. Kilduft T.K. 1994. Engineering Material Technology Structure, Processing, Property and Selection 2. Prentice Hall,Inc A Simon Schuster Company, USA

Jamasri, Diharjo K, et,al, 2005, Kajian Sifat Tarik Komposit Serat Buah SawitAcak Bermatrik Polyester, Media Teknika No. 4 Tahun XXVII Edisi November 2005 No. ISSN 0216-3012, Universitas Gadjah Mada, Yogyakarta.

Melsiani Saduk, et al, 2017, Analisi Kekuatan Bending dan Kekuatan Impact Komposit Epoxy diperkuat serat Pelepah Lontar , Jurnal Rekayasa Mesin Vol.8, No.3 Tahun 2017: 121127 ISSN 2477-6041

Muh. Budi Rahman, et al, 2008, Studi Optimasi Peningkatan Kekuatan Bending Komposit Berpenguat Serat Nanas- Nanasan 
(Bromeliaceae) Kontinu Searah, Jurnal Ilmiah Semesta Teknika, Vol 11 No.2 : 207-2017.

Nurdiana, et al, 2013, Penentuan Kekuatan Tarik Material Komposit Epoxy dengan Pengisi Serat Rockwool Secara Eksperimen Jurnal Dinamis Vol.I,No.13, ISSN 0216-7492

N.V. Rachchh, D.N. Trivedi, 2018, Mechanical Characterization and Vibration Analysis of
Hybrid E-glass/Bagasse Fiber Polyester Composites, ScienceDirect Material Proceedings page 7692-7700

Saurab Dhakal, dan Keerthi Gowda, 2017 An Experimental Study on Mechanical properties of Banana Polyester Composite, ScienceDirect Materials Proceedings 4 (7592-7598) 